\title{
11. The Offshore Renminbi Market and Renminbi Internationalisation
}

William Nixon, Eden Hatzvi and Michelle Wright ${ }^{1}$

\section{Introduction}

The status of the Chinese renminbi (RMB) as an 'international' currency has developed considerably over recent years. This is evidenced by the increasing use of the RMB as a settlement currency for transactions between Chinese residents and non-residents. To date, the internationalisation process has been largely policy-driven. Chinese authorities are, for example, actively encouraging residents to increase their use of RMB in international trade transactions and, more recently, providing non-residents with greater access to RMB investment in the Chinese mainland (and vice versa).

It is apparent, however, that there is still a considerable way to go before the RMB becomes a truly international currency. The RMB, for example, is not yet widely used in transactions between non-residents - a key reason for which is that China's capital account remains partially closed. It follows, then, that the success of the RMB internationalisation agenda will be determined in large part by China's broader path towards capital account liberalisation. That said, the development of an offshore RMB market is also an important part of this process, in that it provides ready access to RMB for use in transactions between non-residents - should there be demand to do so.

There are a number of motivations for RMB internationalisation. One of these is largely symbolic - namely, to ensure that the international usage of the RMB better reflects China's global economic weight. But there are also some other, more direct benefits that could be associated with RMB internationalisation. In particular, greater international usage of the RMB may reduce the currency risk and cost of international trade for Chinese exporters and importers (Frankel 2012). More specifically, if Chinese residents are able to invoice their cross-border transactions in local currency, they will be less exposed to increasing exchange

1 The authors are from the International Department of the Reserve Bank of Australia. The views expressed in this chapter are the authors' own and do not necessarily reflect those of the Reserve Bank of Australia. The authors are solely responsible for any errors. 
rate volatility if China continues to transition from a managed to a freely floating exchange rate regime. This could help to alleviate some of the 'fear of floating' concerns that can arise for many emerging economies during the capital account and exchange rate liberalisation process (Calvo and Reinhart 2002). Further, if Chinese residents are able to settle cross-border transactions in RMB, they will be able to avoid the transaction costs associated with converting RMB into foreign currency (and vice versa).

$\mathrm{RMB}$ internationalisation thus also has the potential to reduce the aggregate currency mismatch on China's international balance sheet. As outlined in Cheung et al. (2011), the combination of China's large and persistent current account surpluses, its managed exchange rate regime and its openness to (mostly RMB-denominated) foreign direct investment (FDI) has led to a large - and rapidly increasing - long foreign currency position. By internationalising the RMB, Chinese residents can potentially increase their RMB-denominated claims on the rest of the world, which would diversify the currency risk embedded in China's overall international asset position.

A final possible motivation for RMB internationalisation is related to there being a close link between RMB internationalisation and capital account liberalisation. Policy initiatives that seek to internationalise the RMB may also have the effect of increasing the flow of RMB between the onshore and offshore markets. Given that there continues to be some debate in China about the merits of capital account liberalisation per se, some commentators consider the goal of RMB internationalisation to be a politically more palatable way for proponents of capital account liberalisation to achieve this objective (Yu 2014).

In light of the important role played by the offshore RMB market in facilitating China's progress towards currency internationalisation, this chapter begins with a brief overview of the features of the offshore market in section two. Drawing on Hatzvi et al. (2014), the chapter then outlines a range of recent policy initiatives that seek to further develop the offshore market, in section three, before discussing their implications for various metrics of RMB internationalisation in section four.

Although there has been significant progress in internationalising the RMB, this does not yet appear to have translated into a reduction in currency mismatch. This conclusion, consistent with Cheung et al. (2011), is explored further in section five. We specifically propose that the internationalisation of the RMB to date could have actually increased the currency mismatch on China's international balance sheet, as the widely held perception (until recently) that the RMB would continue to appreciate steadily against the US dollar is likely to have discouraged non-residents from denominating their liabilities in RMB. However, we also suggest that, in the future, there may be some scaling back 
in these expectations; indeed, there has already been some evidence of this throughout much of 2014 and 2015. If increased two-way flexibility in the $\mathrm{RMB}$ is sustained, this could mean that the RMB internationalisation process may become increasingly associated with a reduction in China's long US dollar position over time.

\section{Overview of the offshore RMB market}

Since the announcement of a pilot scheme for RMB trade settlement in mid-2009, the Chinese authorities have been gradually easing restrictions on the use of RMB outside mainland China. Since mid-2010, the original RMB trade settlement scheme has specifically been expanded to encompass all trade between China and the rest of world, and the RMB has also become fully convertible outside China. This has enabled the creation of a pool of RMB outside the mainland and the development of an offshore RMB market.

Hong Kong initially provided the sole connection between the onshore RMB market and the rest of the world, making it the primary hub of offshore RMB activity. In recent years, several additional official offshore 'RMB centres' have emerged. Although the flow of RMB between the Chinese mainland and the offshore market remains subject to a number of restrictions, RMB is permitted to flow freely between the various official offshore centres, which means that the offshore RMB market is best described as comprising the sum of all activity in these centres (even though most offshore RMB activity continues to occur in Hong Kong). Given that the offshore pool of RMB is freely accessible to market participants outside mainland China, the offshore RMB market can be thought of as providing an environment in which a range of RMB banking products can be developed and in which firms outside mainland China can begin to use the currency, even if they do not have direct access to the onshore market. The ultimate source of both onshore and offshore RMB, however, remains the People's Bank of China (PBC).

There are three main channels through which the size of the offshore pool of RMB can change: trade, income and capital flows (described in further detail in Table 11.1). ${ }^{2}$ To date, RMB payments by Chinese importers have been the primary source of RMB liquidity for the offshore market. This is not surprising, as foreign exporters have an incentive to receive $\mathrm{RMB}$ from their Chinese counterparts so long as there is an expectation that the RMB will continue to appreciate (discussed further in section five).

2 This abstracts from the money multiplier effect where RMB loans offshore would increase the amount of offshore RMB deposits. There are also 'informal' channels that are created by attempts to evade existing capital controls. 
Table 11.1 RMB flows between mainland China and the offshore market

\begin{tabular}{|c|c|c|c|c|}
\hline & \multicolumn{2}{|l|}{ Current account } & \multicolumn{2}{|l|}{ Capital account } \\
\hline & $\begin{array}{l}\text { Trade in goods and } \\
\text { services }\end{array}$ & Income flows & $\begin{array}{l}\text { Direct and } \\
\text { portfolio } \\
\text { investment }\end{array}$ & Other \\
\hline $\begin{array}{l}\text { Flows to } \\
\text { offshore } \\
\text { market }\end{array}$ & $\begin{array}{l}\text { Chinese importers } \\
\text { paying offshore } \\
\text { exporters } \\
\text { Chinese tourists } \\
\text { converting RMB } \\
\text { abroad }\end{array}$ & $\begin{array}{l}\text { Individuals' } \\
\text { remittances } \\
\text { Corporate cross- } \\
\text { border RMB } \\
\text { 'pooling' }\end{array}$ & $\begin{array}{l}\begin{array}{l}\text { RMB- } \\
\text { denominated FDI }\end{array} \\
\text { Shanghai-Hong } \\
\text { Kong Stock } \\
\text { Connect program } \\
\text { RMB Qualified } \\
\text { Domestic } \\
\text { Institutional } \\
\text { Investor program }\end{array}$ & $\begin{array}{l}\text { Foreign central } \\
\text { banks activating } \\
\text { currency swaps } \\
\text { with PBC } \\
\text { Cross-border } \\
\text { RMB loans }\end{array}$ \\
\hline $\begin{array}{l}\text { Flows to } \\
\text { mainland China }\end{array}$ & $\begin{array}{l}\text { Offshore importers } \\
\text { paying Chinese } \\
\text { exporters } \\
\text { Foreign tourists } \\
\text { converting RMB } \\
\text { outside China for } \\
\text { use in the mainland }\end{array}$ & $\begin{array}{l}\text { Individuals' } \\
\text { remittances } \\
\text { Corporate cross- } \\
\text { border RMB } \\
\text { 'pooling' } \\
\text { Repatriated } \\
\text { dim sum bond } \\
\text { issuance }^{\text {a }}\end{array}$ & $\begin{array}{l}\text { RMB- } \\
\text { denominated } \\
\text { overseas direct } \\
\text { investment } \\
\text { Shanghai-Hong } \\
\text { Kong Stock } \\
\text { Connect program } \\
\text { RMB Qualified } \\
\text { Institutional } \\
\text { Investor program }\end{array}$ & $\begin{array}{l}\text { Foreign central } \\
\text { banks unwinding } \\
\text { currency swaps } \\
\text { with PBC } \\
\text { Cross-border } \\
\text { RMB loans }\end{array}$ \\
\hline
\end{tabular}

a Issuance of RMB-denominated bonds in the offshore market, where the funds raised are repatriated back to the mainland. 'Panda' bonds are where foreign firms issue bonds in mainland China, but these cannot generally be repatriated offshore.

Source: Authors' own summary.

Although the capital account liberalisation process to date has led to an increase in RMB-denominated capital flows, the onshore and offshore pools of RMB continue to be partly separated by the capital controls that remain in place. This also means that there are two distinct exchange rates for the RMB: the onshore spot rate (where RMB is denoted as yuan, CNY), which is managed by the $\mathrm{PBC}$ and is accessible only to participants in the mainland market; and the spot rate in offshore markets - the most important of which is Hong Kong (where $\mathrm{RMB}$ is denoted $\mathrm{CNH}$ ) - which is freely floating and accessible to all offshore participants. ${ }^{3}$ The offshore rate tends to track the onshore rate relatively closely, although the two rates can diverge at times (Figure 11.1).

3 Other offshore centres sometimes refer to their own exchange rate- for example, CNT is used to define RMB exchange rates in Taiwan. However, as there are few restrictions on the flow of RMB offshore, the value of offshore RMB should be equivalent at any point regardless of the location within the offshore market. 


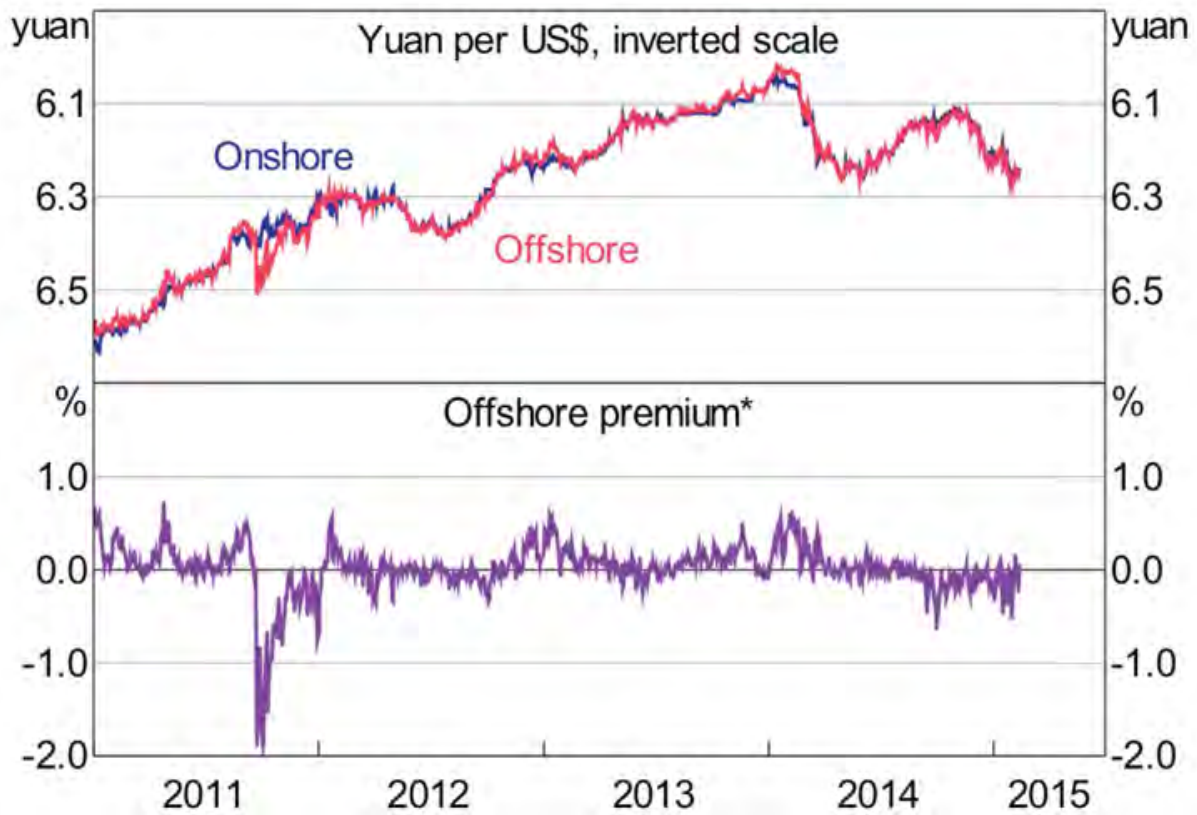

Figure 11.1 Chinese renminbi (RMB per US dollar, inverted scale)

* Negative spread indicates that US\$1 buys more RMB offshore than onshore.

Sources: Bloomberg; RBA.

\section{Recent policy initiatives in the offshore RMB market}

In recent years, a range of policy initiatives has been introduced to further develop the offshore RMB market. These include initiatives that are designed to increase the efficiency of payment system linkages between the onshore and offshore markets - most notably through the establishment of official RMB clearing banks. Other such initiatives seek to increase non-resident participation in RMB markets, such as the Renminbi Qualified Foreign Institutional Investor (RQFII) program, central bank investment in RMB assets, cross-border RMB lending schemes and, most recently, the Shanghai-Hong Kong Stock Connect program.

\section{Official RMB clearing banks}

As with any currency, with the RMB, international use requires the cooperation of domestic banks in China. In particular, offshore banks need access to clearing balances with onshore banks in order to facilitate RMB transactions in the offshore market. 
With that in mind, the internationalisation of the RMB began in late 2003 when the Chinese authorities appointed the Bank of China, Hong Kong (BOCHK), the first official 'RMB clearing bank' outside mainland China. This meant BOCHK could accept RMB deposits from offshore banks and place them with the PBC's Shenzhen sub-branch. In turn, BOCHK could clear and settle RMB transactions in the offshore market. As part of its clearing bank status, BOCHK was also granted a quota to transact directly within China's onshore interbank foreign exchange (FX) market, enabling it to square foreign currency positions arising from 'participating' bank transactions. ${ }^{4}$ Alongside BOCHK's new rights, foreign branches and subsidiaries of mainland Chinese banks began to offer 'correspondent' banking services to offshore banks. Those services provide offshore banks with an additional channel via which to clear and settle RMB transactions with their mainland Chinese counterparts, essentially by allowing offshore banks to open RMB accounts at banks in mainland China.

In recent years, the Chinese authorities have designated official RMB clearing banks in a wide range of jurisdictions outside Hong Kong. As of April 2015, there were 15 official clearing banks worldwide, all of which are offshore branches of Chinese banks, including one in Australia (Table 11.2). The primary purpose of these clearing banks is to facilitate cross-border RMB payments between the onshore and offshore RMB markets, and within the offshore market itself. Similar to BOCHK, these clearing banks are permitted to maintain onshore RMB balances to facilitate RMB transactions on behalf of their local participating banks. They also have more direct access to RMB liquidity from the PBC and are permitted to transact directly within China's onshore interbank foreign exchange market, subject to a quota.

Table 11.2 RMB clearing banks, as of 4 May 2015

\begin{tabular}{|l|l|l|}
\hline Centre & Date announced & Bank \\
\hline Hong Kong & Dec 2003 & Bank of China \\
\hline Macau & Jun 2004 & Bank of China \\
\hline Taipei & Dec 2012 & Bank of China \\
\hline Singapore & Feb 2013 & ICBC \\
\hline London & Mar 2014 & China Construction Bank \\
\hline Frankfurt & Mar 2014 & Bank of China \\
\hline Luxembourg & Jun 2014 & ICBC \\
\hline Paris & Jun 2014 & Bank of China \\
\hline Seoul & Jul 2014 & Bank of Communications \\
\hline Doha & Nov 2014 & ICBC \\
\hline
\end{tabular}

4 Participating banks hold accounts with a clearing bank for the purpose of clearing RMB transactions. 


\begin{tabular}{|l|l|l|}
\hline Centre & Date announced & Bank \\
\hline Toronto & Nov 2014 & Bank of China \\
\hline Kuala Lumpur & Nov 2014 & Bank of China \\
\hline Sydney & Nov 2014 & Bank of China \\
\hline Bangkok & Dec 2014 & ICBC \\
\hline Zurich & Jan 2015 & - \\
\hline
\end{tabular}

Sources: RBA; SAFE.

Prior to the establishment of RMB clearing banks in these other offshore centres, local banks were able to effect RMB transactions through two channels: by participating in another offshore clearing bank's payments system (most likely BOCHK); or by making use of 'correspondent banking' relationships with banks in mainland China (discussed above). The primary benefit of using a local official clearing bank rather than a non-local offshore clearing bank or a correspondent banking relationship is that it can provide a more direct method of effecting payments (for example, a reduction in settlement delays). Over time, this could improve the efficiency and/or lower the transaction costs of such payments. The official status of these clearing banks also means that they play an important symbolic role in establishing recognised offshore RMB centres, especially by raising awareness and confidence among firms in these jurisdictions about their local financial sectors' capacity to facilitate RMB transactions.

That said, it is possible that the role of clearing banks (along with the other alternative mechanisms for effecting cross-border RMB payments) could diminish over time. Chinese authorities are in the process of developing the China International Payments System (CIPS), which is expected to give all offshore banks the opportunity to acquire access to China's domestic payments system and foreign exchange market. The development of CIPS, therefore, has the potential to foster significant further development of the offshore market. The process, however, may take some time to complete. Hence, offshore RMB clearing banks are likely to play a central role in connecting offshore financial institutions and their non-financial customers to their counterparts in China for some time yet.

\section{Central bank initiatives}

Central banks have also undertaken a number of initiatives that seek to support the development of the offshore RMB market, including bilateral currency swap agreements, RMB liquidity facilities and RMB investments.

The PBC has, as of February 2015, signed bilateral currency swap agreements with 28 central banks (Figure 11.2). Under these agreements, foreign central banks can exchange their local currency for RMB with the PBC (that is, RMB 
obtained from the onshore market) for mutually agreed purposes. This enables foreign central banks to provide RMB liquidity to the offshore market during times of market stress or, in some cases, simply to promote the development of the offshore RMB market. By providing an assurance that market participants can approach their local central bank to access RMB liquidity if required, central bank swap lines support the development of the local RMB market. Swap lines range in size from RMB700 million (Uzbekistan) to RMB400 billion (Hong Kong). There is relatively little publicly available information on the extent to which these swap lines have been activated. It is, however, known that Hong Kong, Singapore, South Korea and Argentina have all activated their swap lines (for non-test purposes).

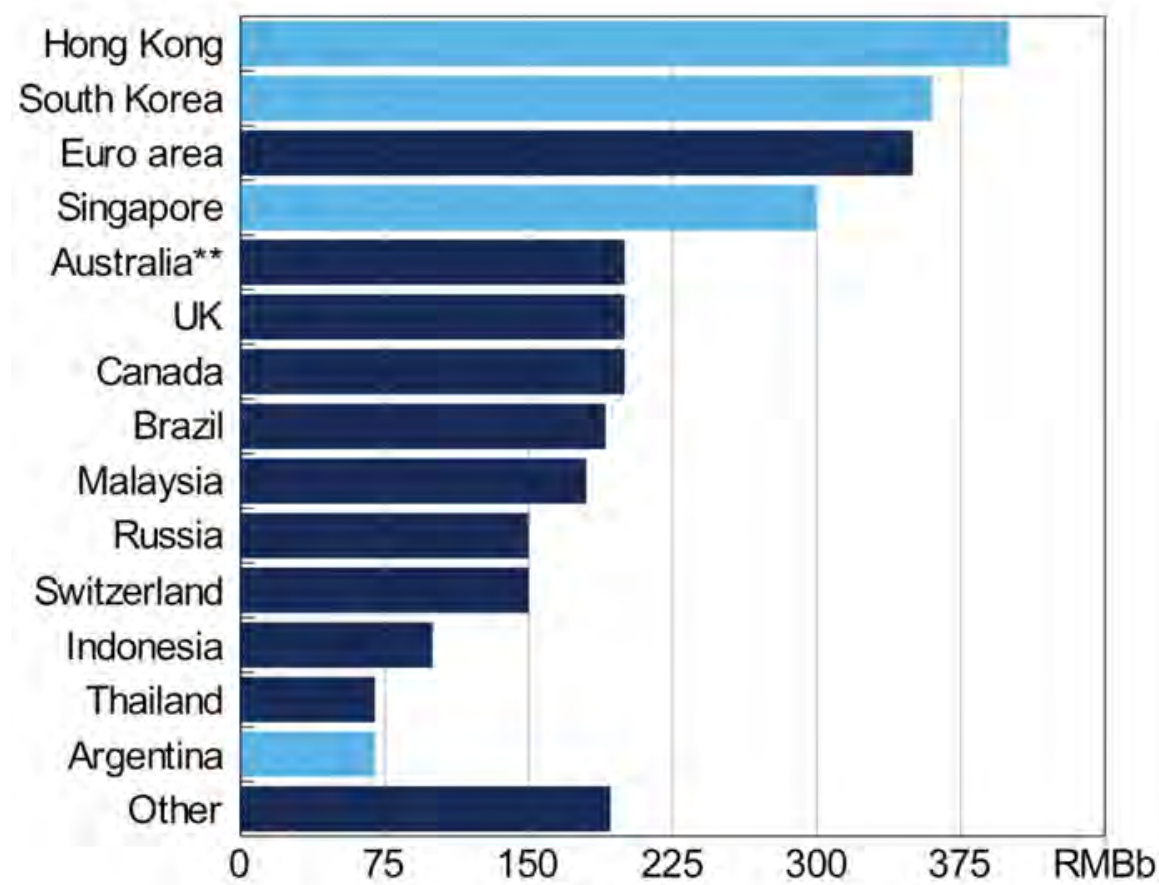

Figure 11.2 PBC local currency swap agreements

Note: A light-blue bar indicates that some portion of the swap line has been activated as of February 2015 (based on publicly available information).

Sources: PBC; RBA.

Some central banks have also established RMB liquidity facilities to provide short-term RMB funds to offshore market participants, in some cases using their swap agreements with the PBC. These additional measures are designed to further ensure market participants have confidence in the availability of liquidity in the offshore RMB market. Specifically, the Hong Kong Monetary Authority (HKMA) and the Monetary Authority of Singapore (MAS) both offer eligible financial institutions access to overnight RMB loans. The MAS also 
allows participants in Singapore's payments system to access three-month RMB loans for trade-related purposes. Further, in anticipation of additional demand for offshore RMB following the launch of the Shanghai-Hong Kong Stock Connect program (discussed below), the HKMA has introduced an intraday RMB repurchase agreement (repo) facility to provide up to RMBl0 billion to banks in Hong Kong. ${ }^{5}$

In recent years, at least 40 central banks have also begun to invest a portion of their foreign exchange reserves in RMB-denominated assets (BOCHK 2014). For example, the Reserve Bank of Australia (RBA) now holds 5 per cent of its total foreign exchange reserves in RMB-denominated assets (RBA 2014). ${ }^{6}$ While this does not directly influence the offshore RMB market per se, as these reserves are typically held in the form of RMB-denominated assets in mainland China, it is an important component of the broader RMB internationalisation process. Reserve asset holdings are a key characteristic of an international currency.

\section{The RMB Qualified Foreign Institutional Investor (ROFII) program}

The expansion in the number of official RMB clearing banks and currency swap agreements should increase demand for offshore RMB by increasing market participants' confidence that cross-border RMB transactions can be effected efficiently and predictably. Chinese authorities have recently taken a number of further steps to increase the investment options available to offshore holders of $\mathrm{RMB}$, and thereby support the development of the market by increasing market participants' willingness to take on RMB exposures. For example, offshore RMB can now be used to make investments in mainland China, primarily via the RQFII program. This allows approved foreign investors to buy and sell designated assets in China's onshore equity and bond markets. The RQFII program can thus be thought of both as being part of China's broader capital account liberalisation process and as an initiative that is designed to encourage broader participation in the offshore RMB market.

Importantly, the RQFII program is only available to investors with operations in a jurisdiction that has been granted an RQFII quota by the Chinese authorities. The RQFII program was initially made available only to Hong Kong-domiciled

5 Additionally, the HKMA designated a number of banks as primary liquidity providers (PLPs). The HKMA will offer PLPs an RMB repo line (to obtain both intraday and overnight funds) to ensure that they have sufficient liquidity available to perform market-making functions in Hong Kong's offshore market.

6 The Reserve Bank's investment makes use of a scheme commonly known as the China Interbank Bond Market scheme, which is separate to the QFII and RQFII programs (discussed below) and is typically used by central banks and sovereign wealth funds. 
investors, with a quota of RMB20 billion granted in 2011. Hong Kong's quota has since been incrementally raised to RMB270 billion. From the middle of 2013 to April 2015, RQFII quotas totalling RMB600 billion (A \$123 billion) have also been granted to a range of other offshore centres, including Australia (Table 11.3).

Table 11.3 RQFII quotas, as at 4 May 2015

\begin{tabular}{|l|r|r|r|}
\hline Centre & $\begin{array}{r}\text { Quota } \\
\text { (RMB b) }\end{array}$ & Date announced & $\begin{array}{r}\text { Allocation to date } \\
\text { (RMB b) }\end{array}$ \\
\hline Hong Kong & 270 & Dec 2011 & 270.0 \\
\hline Singapore & 50 & Oct 2013 & 26.0 \\
\hline United Kingdom & 80 & Oct 2013 & 15.2 \\
\hline France & 80 & Mar 2014 & 6.0 \\
\hline Germany & 80 & Jul 2014 & 6.0 \\
\hline South Korea & 80 & Jul 2014 & 30.5 \\
\hline Oatar & 30 & Nov 2014 & n.a. ${ }^{b}$ \\
\hline Canada & 50 & Nov 2014 & n.a. \\
\hline Australia & 50 & Nov 2014 & 10.0 \\
\hline Switzerland & 50 & Jan 2015 & n.a. \\
\hline Luxembourg & 50 & Apr 2015 & n.a. \\
\hline
\end{tabular}

a The activation of Taiwan's ROFII quota is conditional on the finalisation of the Cross-Strait Trade in Service Agreement.

${ }^{\mathrm{b}}$ n.a. $=$ not applicable.

Sources: PBC; SAFE.

As of April 2015, about 80 Hong Kong-domiciled entities had been granted RQFII licences. Outside Hong Kong, about 40 firms have acquired quotas, although more are in the process of applying (the process typically takes about six months). Once a firm has acquired a quota, it is able to offer RMB investment products to a broad range of investors, including those located outside its original jurisdiction. For example, some Hong Kong-domiciled firms have partnered with US and Europe-domiciled financial institutions to launch exchange-traded funds on foreign stock exchanges, including the New York Stock Exchange and the London Stock Exchange. This allows investors without an RQFII quota to gain exposure to China's equity and bond markets.

The RQFII program is in addition to the Qualified Foreign Institutional Investor (QFII) program, which has been in place since 2003. The QFII program permits approved foreign investors to use foreign currency to invest in designated Chinese financial assets. Unlike the RQFII program, the QFII program has no jurisdiction-specific quotas. From an investor's perspective, however, the RQFII program has several potential advantages over the QFII program - among them, greater discretion in portfolio allocation and less restrictive rules regarding the 
repatriation of funds. The RQFII program also permits authorised investors to invest part of their RQFII quota in China's fixed-income interbank bond market, whereas QFII-approved investors must apply for an additional quota to access this market. As of the end of April 2015, the total value of allocated quotas under the RQFII program was about RMB364 billion, with an additional RMB506 billion worth of aggregate global RQFII quotas yet to be allocated. This compares with about RMB457 billion of allocation for the QFII program (Figure 11.3). As investors utilise their jurisdictions' quotas, the RQFII program is likely to account for more foreign investment in Chinese financial assets than the QFII program.

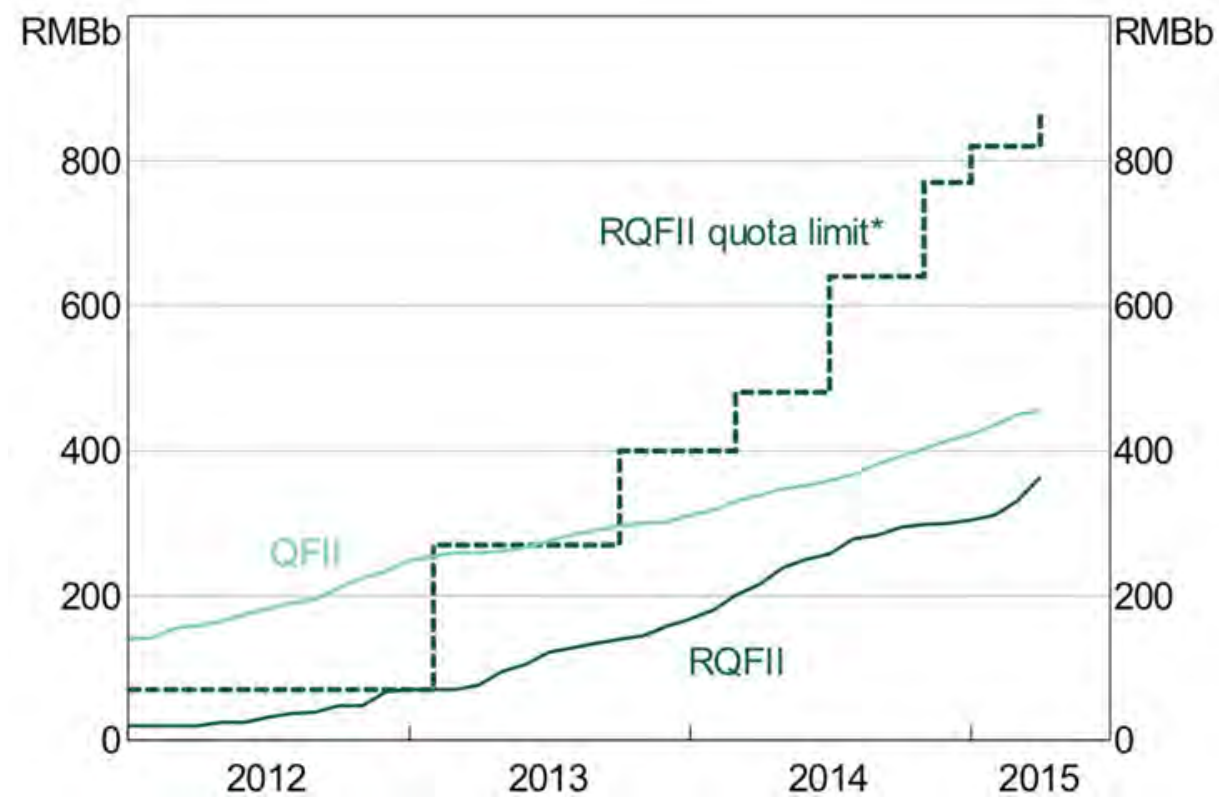

Figure 11.3 Foreign investment in Chinese financial assets (accumulated approved quotas)

*Excludes Taiwain's ROFII quota.

Sources: CEIC Data; RBA, SAFE.

\section{Shanghai-Hong Kong Stock Connect program}

In addition to the RQFII program, the other key policy initiative aimed at increasing the attractiveness of offshore RMB (from the perspective of foreign investors) is the Shanghai-Hong Kong Stock Connect program. The program, which began operating in November 2014, allows offshore investors to purchase approved (RMB-denominated) stocks listed on the Shanghai Stock Exchange (SSE) - known as 'northbound' trading. Similarly, eligible mainland investors are able to purchase (Hong Kong dollar-denominated) stocks listed on the 
Hong Kong Stock Exchange (HKEx) - known as 'southbound' trading. In other words, the Stock Connect program provides an additional avenue through which offshore (onshore) investors can buy and sell Chinese (Hong Kong) equities in addition to the RQFII and QFII programs, and therefore is an additional link between the offshore and onshore RMB markets.

Purchases in both exchanges are subject to total and daily quotas (Table 11.4). Offshore investors are permitted to purchase a total of RMB300 billion worth of SSE stocks (daily quota of RMB13 billion). Mainland Chinese investors are permitted to purchase a total of RMB250 billion worth of HKEx stocks (daily quota of RMB10.5 billion) (Table 11.4). Like the RQFII program, the currency exchange takes place in the offshore market, so investors must purchase (sell) $\mathrm{RMB}$ in the offshore market in order to buy mainland (Hong Kong) stocks.

Table 11.4 Features of the Stock Connect program

\begin{tabular}{|l|l|l|}
\hline & $\begin{array}{l}\text { Northbound trading } \\
\text { Hong Kong to Shanghai }\end{array}$ & $\begin{array}{l}\text { Southbound trading } \\
\text { Shanghai to Hong Kong }\end{array}$ \\
\hline Daily quota ${ }^{a}$ & RMB13 billion & RMB10.5 billion \\
\hline Aggregate quota & RMB300 billion & RMB250 billion \\
\hline Eligible investors & All foreign investors & $\begin{array}{l}\text { Institutional Chinese investors, mutual } \\
\text { funds and high net-worth Chinese } \\
\text { individuals }\end{array}$ \\
\hline $\begin{array}{l}\text { Eligible index } \\
\text { constituents }\end{array}$ & SSE 180 Index and SSE 380 Index & $\begin{array}{l}\text { Hang Seng Composite LargeCap Index } \\
\text { and Hang Seng Composite MidCap Index }\end{array}$ \\
\hline
\end{tabular}

a Daily limits operate on a 'first come, first served' basis. Daily quota balances are calculated on a 'net buy' basis and are adjusted when a buy order is cancelled, rejected by the other exchange or executed at a better price.

${ }^{b}$ Individuals with more than RMB500,000 in their brokerage accounts.

Source: Hong Kong Exchanges and Clearing Limited (HKEx).

Early trading via the Stock Connect program was heavily skewed towards Shanghai-listed stocks. The daily northbound quota was exhausted on the first day of trading, while less than 20 per cent of the daily southbound quota was used. However, southbound trading increased markedly in April 2015 alongside a broadening of eligible mainland investors to include mutual funds. As of April 2015, investors have used some 43 per cent of the aggregate northbound quota and 34 per cent of the aggregate southbound quota (Figure 11.4). 


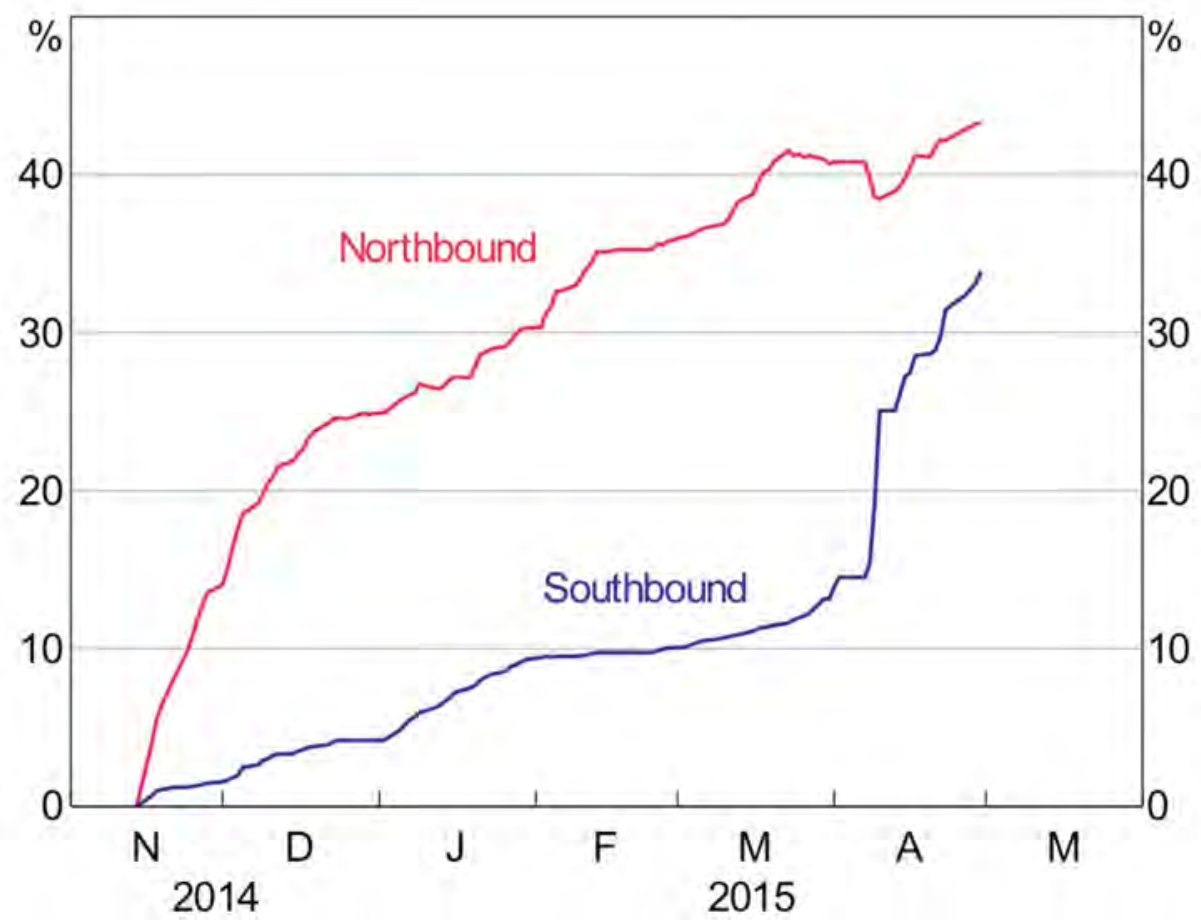

Figure 11.4 Shanghai-Hong Kong Stock Connect program (aggregate quota used)

Source: Hong Kong Exchanges and Clearing Limited (HKEx).

The primary advantage of the Stock Connect program over the RQFII program is that it is open to all foreign investors, whereas the RQFII program is restricted to financial institutions domiciled in countries that have been granted RQFII quotas (although once an institution obtains an RQFII quota, it can use this to set up RMB products elsewhere). Moreover, gaining an RQFII licence and quota for individual institutions is a comparatively lengthy process.

Nevertheless, the RQFII program is likely to continue to be used as it has some advantages over the Stock Connect program. Importantly, institutions with an RQFII quota can invest in mainland fixed-income assets and a broader range of mainland stocks. In addition, while Stock Connect investors are subject to an aggregate daily quota (for the market as a whole) and execution queues, RQFII investors can transact subject only to their own individual quotas. The two programs are nonetheless partial substitutes. Since Hong Kong has exhausted its aggregate RQFII quota, some Hong Kong-based entities have reportedly requested to be allowed to transfer stocks bought under the RQFII program to the Stock Connect program in an attempt to free up space in their existing RQFII quotas. 


\section{RMB cross-border lending schemes}

In addition to the RQFII and Stock Connect programs - which seek to increase the cross-border flow of RMB-denominated portfolio investment - there are a number of pilot schemes that permit RMB-denominated lending flows. Such schemes typically only permit flows between designated mainland Chinese cities or regions and specific offshore centres, and are therefore not available to all offshore market participants. The first of these schemes, established in January 2013, allows companies incorporated in Qianhai - a special economic zone (SEZ) within the Chinese city of Shenzhen - to borrow RMB from banks in Hong Kong to fund investment projects within Qianhai. As interbank RMB interest rates have typically been noticeably lower in Hong Kong than in the mainland (notwithstanding some narrowing in the onshore-offshore spread in the latter half of 2014), it is possible the scheme has provided Qianhai firms with access to cheaper funding. ${ }^{7}$

In 2014, similar schemes were established between Singapore-based banks and firms in China's Suzhou Industrial Park, in Jiangsu Province, and Tianjin Eco-City, as part of a broader range of initiatives between the Chinese and Singaporean governments to develop these two innovation-oriented initiatives. Entities within the zone of both initiatives have also been permitted to issue RMB-denominated bonds in Singapore and to undertake direct investment in Singapore-based corporations.

Another scheme, with Taiwan, was established in late 2013 and follows a slightly different model. Under this scheme, subsidiaries of Taiwanese firms in the Jiangsu city of Kunshan, near Shanghai, are permitted both to borrow RMB from their offshore parent companies and to extend RMB loans to them. In addition, and most recently, non-bank financial institutions and enterprises domiciled in the Shanghai Free Trade Zone have been permitted to borrow RMB from any offshore centre, subject to certain conditions. ${ }^{8}$

\section{Recent progress towards RMB internationalisation}

Partly through the policy initiatives outlined above, China has made significant progress in internationalising its currency in the past few years. This is evident in part by the fact that China's RMB-denominated current account transactions

7 Interest rates are privately negotiated between borrowers and lenders and are therefore not publicly available.

8 The funds must be put towards manufacturing operations and project construction within the zone and their value cannot exceed specified limits. 
have grown rapidly, and now account for about one-fifth of China's total current account transactions (Figure 11.5). RMB-denominated investment (particularly inward investment) has also increased noticeably in recent years, but remains small relative to the value of RMB-denominated trade settlement.

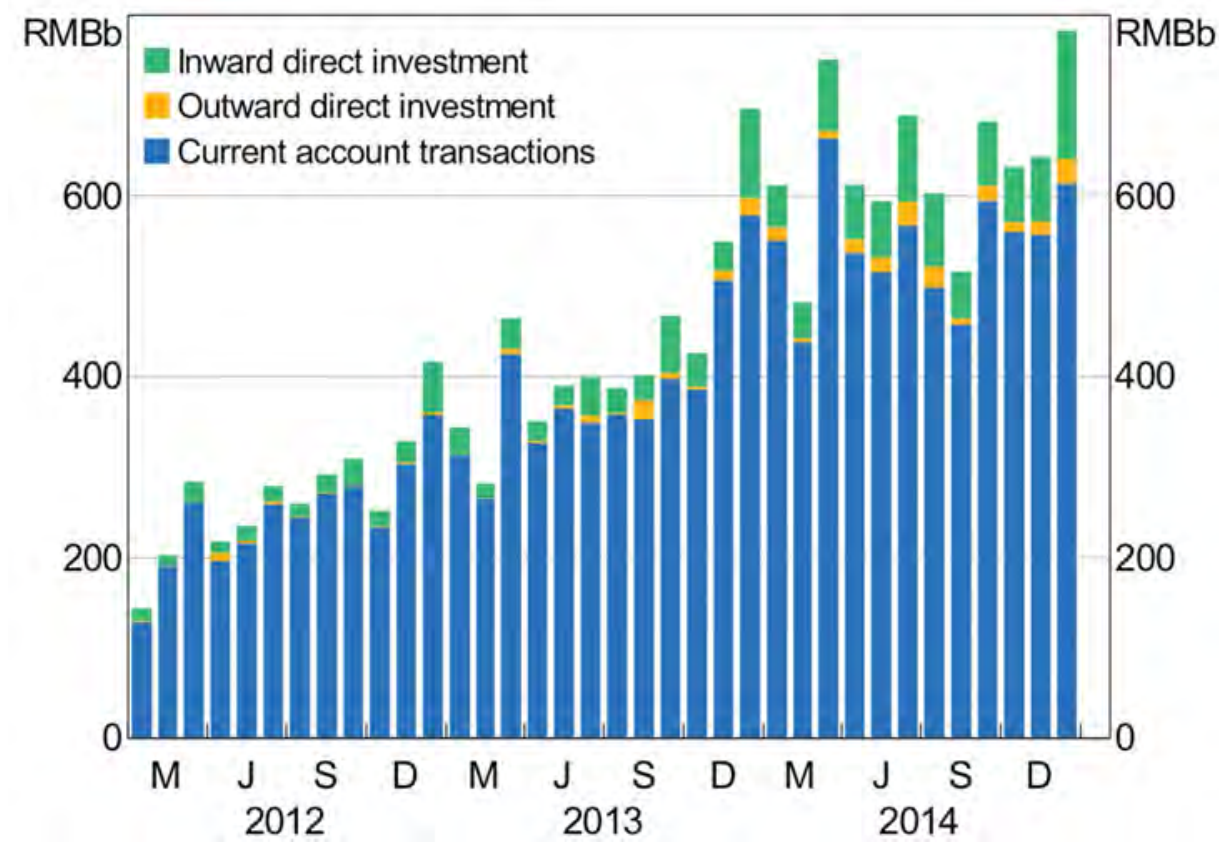

Figure 11.5 Cross-border RMB settlement

Sources: CEIC Data; RBA.

By economic jurisdiction, Hong Kong continues to account for the majority of China's RMB-denominated cross-border transactions, followed by Singapore and Taiwan. This is unsurprising given that Hong Kong remains the centre of the offshore RMB market. Nevertheless, the launch of official RMB clearing banks in Singapore and Taiwan in early 2013 coincided with a substantial increase in the RMB-denominated share of each economy's bilateral merchandise trade with China in 2013 (Figure 11.6). The share of China's merchandise trade settled in RMB with economies excluding Hong Kong, Taiwan and Singapore increased slightly in 2013, but, in comparison, remained relatively low at about 3 per cent. 


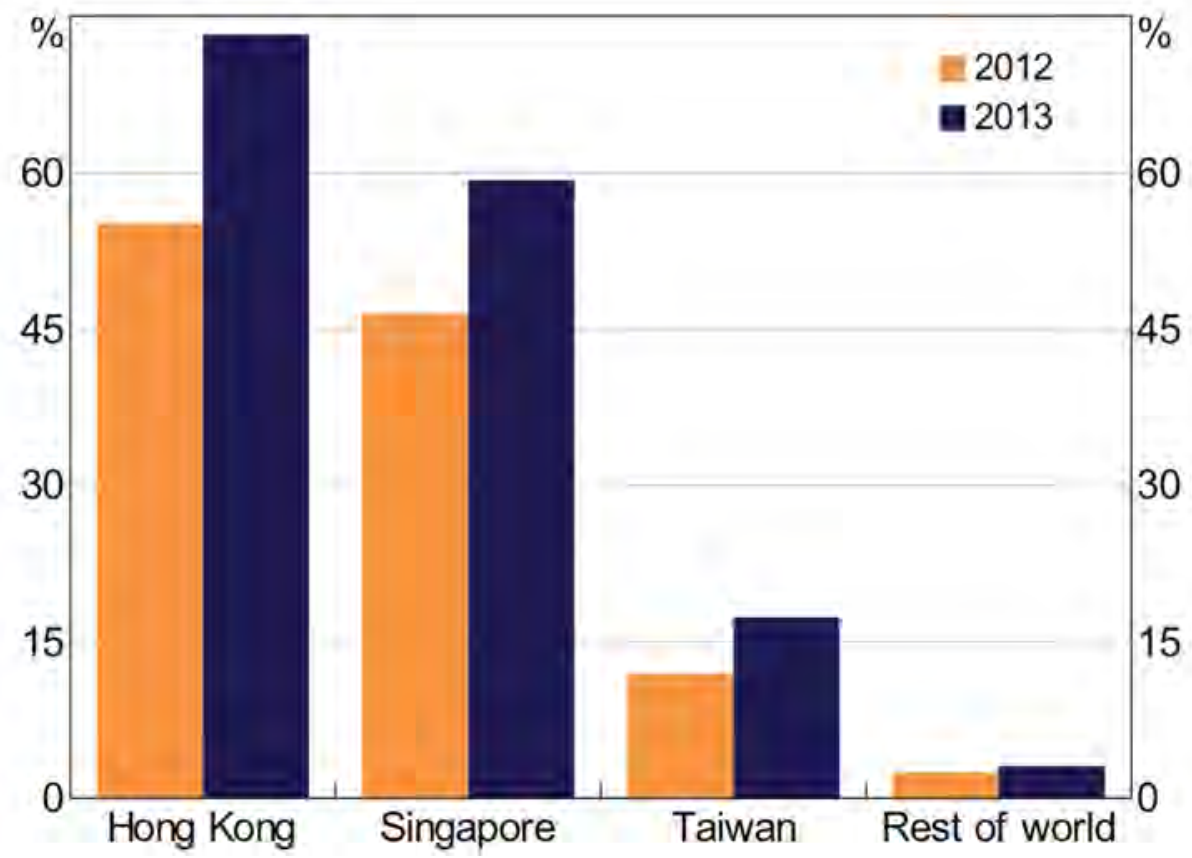

Figure 11.6 Bilateral RMB trade settlement, as a share of total bilateral merchandise trade with China

Sources: CEIC Data; PBC; RBA.

Importantly, while the share of trade settled in RMB has increased markedly, it is not clear whether the share of trade invoiced in RMB has increased to the same extent. Relatively few data are available on invoicing. The distinction is important because the extent of trade settlement in RMB could partly reflect differences in the value of onshore and offshore RMB. This could mean the settlement data are overstating underlying demand for RMB.

Notwithstanding China's overall current account surplus, the value of China's cross-border RMB payments (for example, for imports) typically exceeds the value of China's cross-border RMB receipts (for example, from exports) (Figure 11.7). In other words, China runs a current account surplus but an RMB-denominated deficit for trade denominated in RMB. One potential reason for this is that Chinese firms may have been attempting to benefit from the typically higher value of offshore RMB relative to onshore RMB (also known as the offshore premium, and shown in Figure 11.1). For example, when the RMB buys more US dollars in the offshore market than in the onshore market, Chinese importers have an incentive to exchange RMB for US dollars in the offshore market to meet 
US dollar payments. From China's perspective, such a transaction will be counted as RMB trade settlement even though, from the perspective of the foreign firm, the underlying trade flow is both settled and invoiced in US dollars. ${ }^{9}$

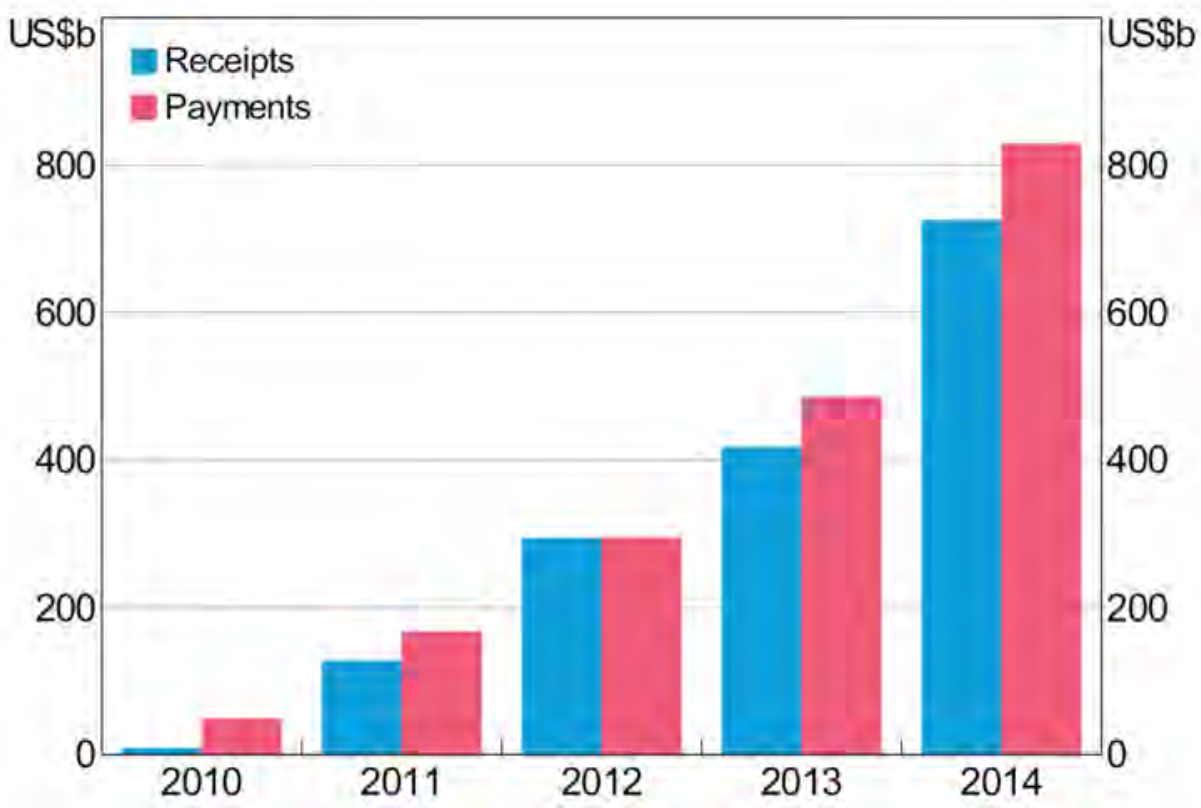

Figure 11.7 Cross-border RMB receipts and payments

Sources: CEIC Data; RBA; SAFE.

In any case, the net outflow of RMB from China in recent years has led to a rapid increase in the stock of RMB deposits in offshore centres, although growth slowed somewhat in 2014 (Figure 11.8). While Hong Kong continues to account for the majority of offshore RMB deposits, the stock of deposits in Taiwan and Singapore has increased rapidly since early 2013, respectively rising to about RMB300 billion and RMB280 billion at the end of December 2014.

9 Likewise, when the RMB buys fewer US dollars in the offshore market, Chinese exporters have an incentive to exchange their US dollar receipts for RMB in the offshore market (rather than the onshore market) before sending the receipts back to the mainland. Again, this will count towards RMB trade settlement even though the underlying trade flow is settled and invoiced in RMB from the foreigner's perspective. 


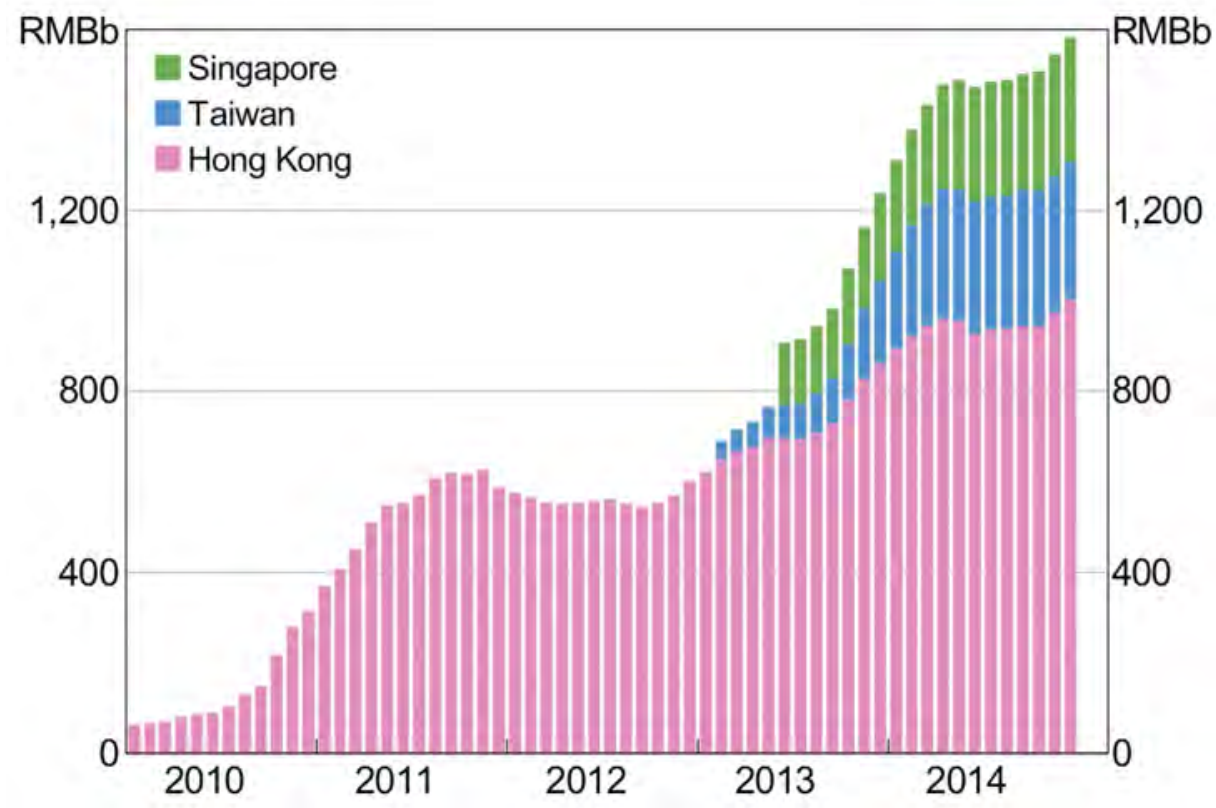

Figure 11.8 Value of RMB deposits

Sources: CEIC Data; MAS.

As the pool of offshore RMB deposits has grown, so too has the offshore RMBdenominated bond market. Hong Kong remains the prime location for offshore $\mathrm{RMB}$ bond - or 'dim sum' bond-issuance, but the market is also growing rapidly in Singapore, Taipei and Luxembourg. The majority of issuers continue to be mainland Chinese companies or offshore subsidiaries of mainland Chinese companies (Figure 11.9). Funds raised are typically repatriated back to mainland China. Most of the dim sum bond issuance by other firms has also been used to fund their operations in mainland China.

One reason for the prevalence of mainland Chinese issuers in the dim sum bond market is that the cost of funding has typically been lower in the offshore market than on the mainland. This is evidenced, for example, by the consistently lower yield paid on Chinese government bonds issued in the offshore market relative to those issued in the onshore market (Figure 11.10). This is partly because capital account restrictions limit the flow of offshore RMB back to the mainland, such that there is a large pool of RMB in offshore markets with relatively limited investment opportunities (and therefore strong demand for dim sum bonds from offshore investors). However, recent policy initiatives aimed at increasing the flow of RMB between the offshore and onshore markets (for example, the Stock Connect program and cross-border lending schemes) have begun to reduce this gap. 


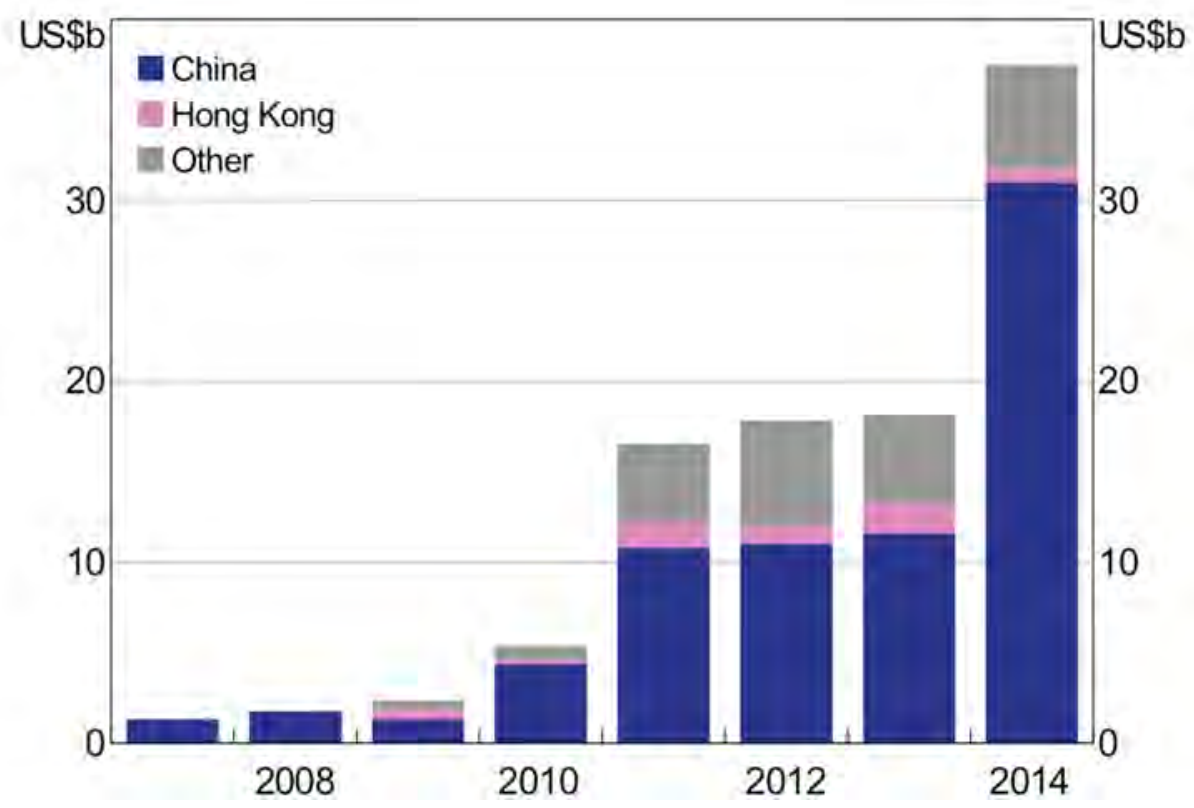

Figure 11.9 Dim sum bond issuance, by nationality of parent issuer Source: Dealogic.

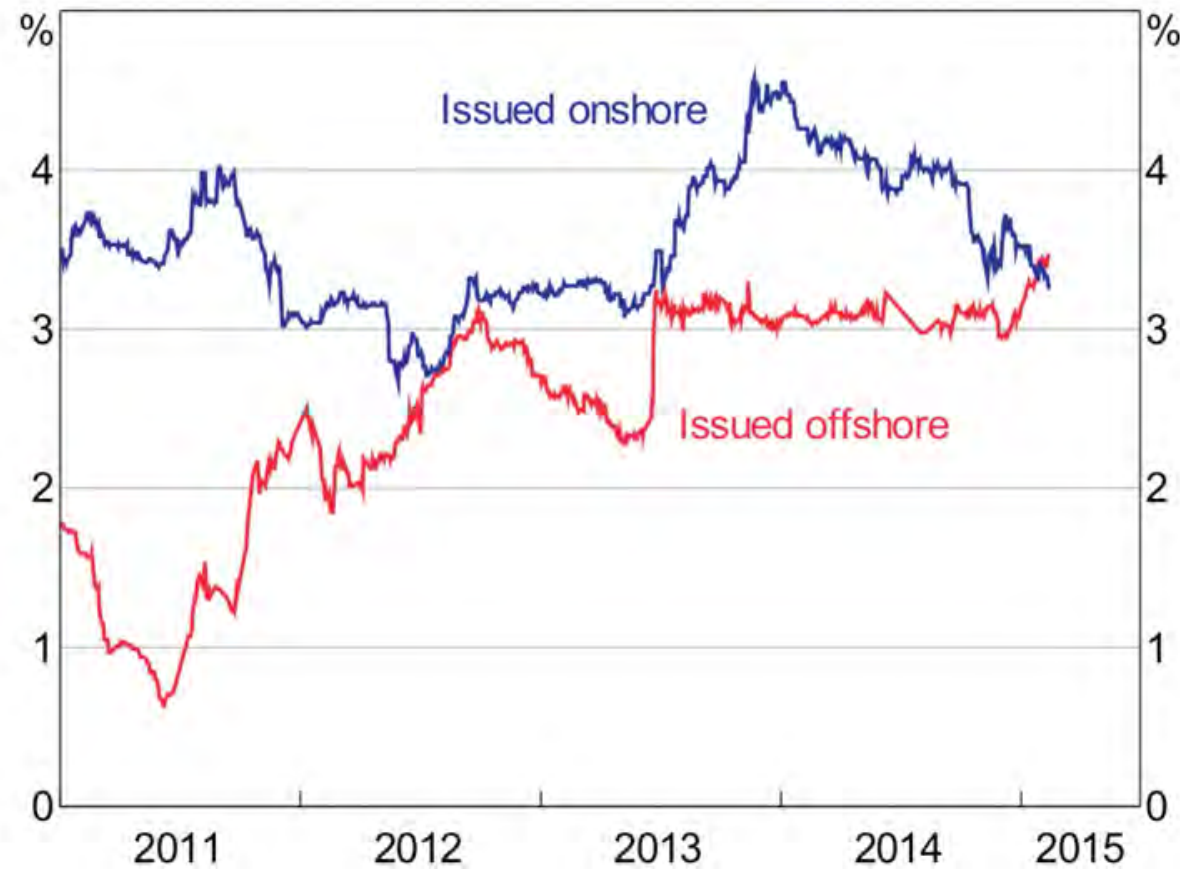

Figure 11.10 Chinese five-year government bond yields

Sources: Bloomberg; RBA. 
There have also been a small number of offshore RMB bond issues by foreign governments, with the UK Government raising RMB3 billion in October 2014 and the NSW Treasury Corporation raising RMB1 billion in November 2014. This followed the Canadian Province of British Columbia's issuance of an RMB2.5 billion dim sum bond in late 2013. Some foreign banks have also tapped the market. ANZ, for example, became the first foreign issuer to sell a Basel III-compliant RMB-denominated capital instrument when it issued an RMB2.5 billion dim sum bond in January 2015. Moreover, bond issuers have used the offshore RMB swap market to hedge their foreign currency risk. For example, the NSW Treasury Corporation swapped the proceeds from its RMB bond issue into Australian dollars.

\section{RMB internationalisation and currency mismatch}

As outlined in Cheung et al. (2011), the combination of China's large and persistent current account surpluses, its managed exchange rate regime and its openness to (mostly RMB-denominated) FDI has led to a large currency mismatch in the past decade. The value of China's foreign currency assets has correspondingly far exceeded the value of its foreign currency liabilities. In other words, years of foreign currency reserve accumulation by the PBC have produced a substantial long US dollar position (Figure 11.11). As a result, an appreciation of the RMB against the US dollar leads to a decline in the value of China's net international asset position (in RMB terms).

Against this background, one potential motive for RMB internationalisation is to increase China's RMB-denominated foreign assets and thus reduce China's exposure to an appreciation of the RMB. For example, if a Chinese resident purchased a dim sum bond issued by a non-resident, and the non-resident used the proceeds to purchase goods from a Chinese exporter, China's RMB-denominated claims on the rest of the world would increase (all else remaining constant). 


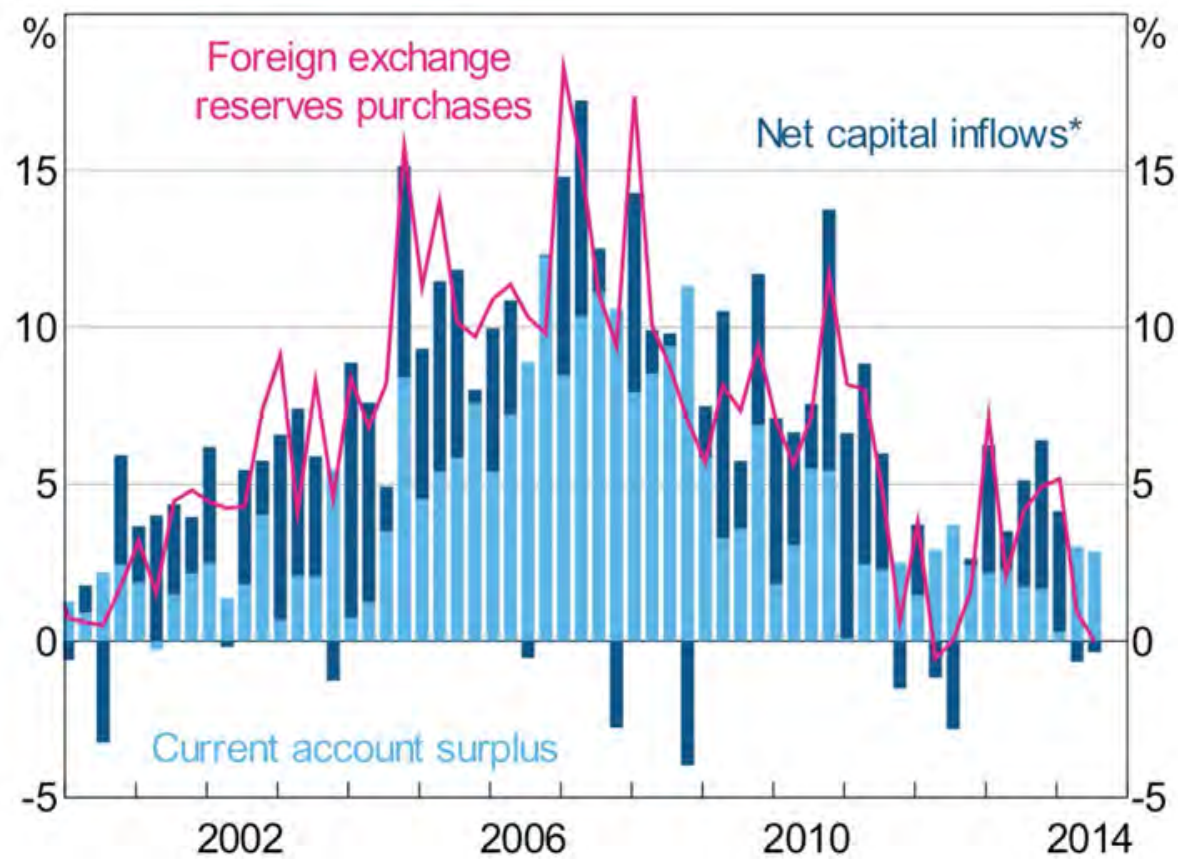

Figure 11.11 China's balance of payments (quarterly flows, percentage of GDP)

*Excluding foreign exchange reserves.

Sources: CEIC Data; IMF; RBA.

The RMB internationalisation process to date has, however, likely worsened the currency mismatch between China's international assets and liabilities. One reason for this is that, by design, the policy initiatives so far announced (such as RQFII and Stock Connect) have had the effect of increasing China's RMBdenominated foreign liabilities, rather than increasing its RMB-denominated foreign assets. ${ }^{10}$ Another reason is that the net outflow of RMB from China's cross-border trade in recent years has led to an increase in the stock of RMB deposits in offshore centres, which has also increased China's RMB-denominated foreign liabilities. This outcome likely reflects the fact that, until recently, market participants have typically expected the RMB to continue to appreciate against the US dollar. In effect, foreigners have been discouraged from denominating their liabilities in RMB because they expect the RMB to experience a significant real appreciation against the US dollar. (For a full discussion of the relationship between RMB trade settlement, RMB appreciation and currency mismatch, see the Appendix for this chapter.) 
Against this background, the extent to which market participants perceive the $\mathrm{RMB}$ to be undervalued or overvalued is an important consideration when trying to assess the outlook for RMB internationalisation - and is especially so of the extent to which this process is likely to translate into a reduction in aggregate currency mismatch on China's international balance sheet. Specifically, if firms continue to view RMB appreciation against the US dollar as a 'one-way' bet, there would likely be a continuation of the trend of recent years of net RMB outflows from trade settlement, net RMB capital inflows and a further increase in the degree of currency mismatch. This trend could reverse if participants come increasingly to expect greater two-way movements in the RMB exchange rate.

A number of reports suggest that market participants have either scaled back their expectations for future RMB appreciation against the US dollar or now expect the RMB to depreciate against the US dollar (Figure 11.12) (see, for example, Wildau 2015). These expectations may have arisen for a number of reasons, but have likely been reinforced by the fact that the RMB has increasingly been trading near the lower bound of its daily trading band against the US dollar in the onshore market. Relatedly, there has been a marked slowdown in the pace of $\mathrm{PBC}$ reserve accumulation. Moreover, Chinese officials have indicated their desire to see greater two-way volatility in the RMB's exchange rate (PBC 2014).

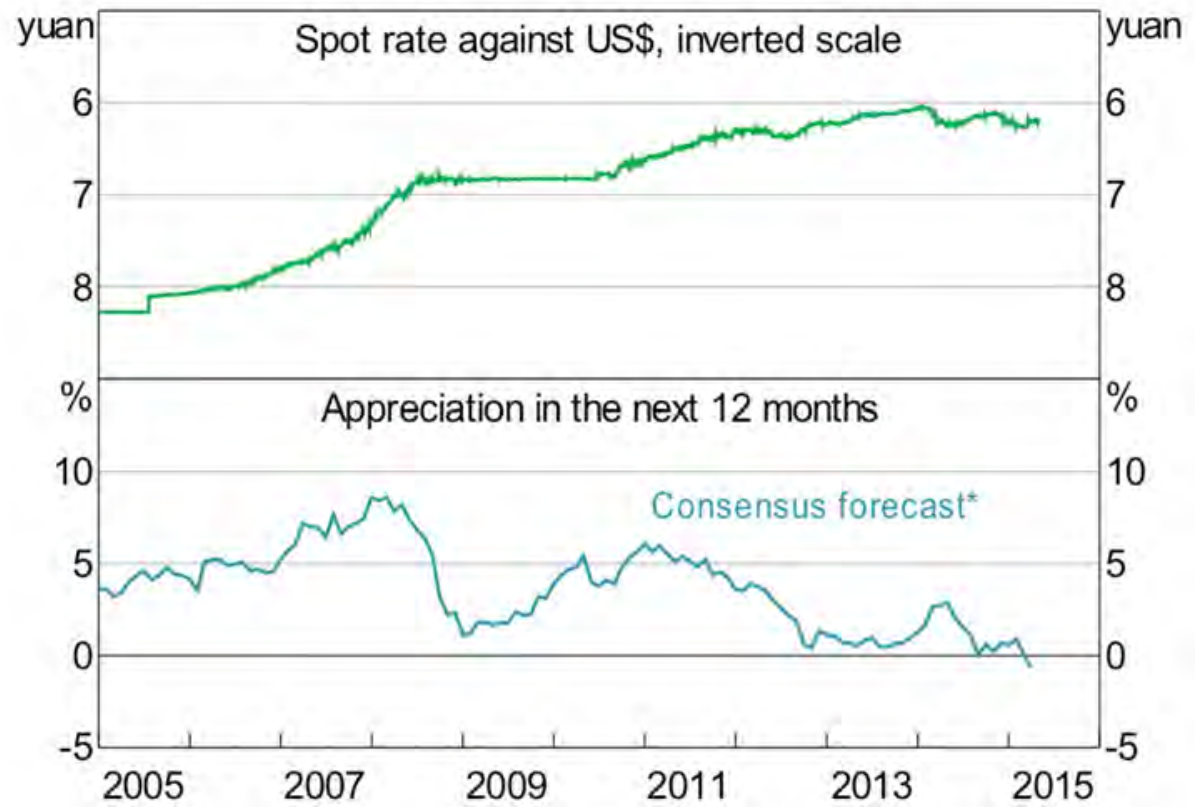

Figure 11.12 Chinese RMB (spot rate against US dollar, inverted scale)

* Mean estimate of forecasters polled by Consensus.

Sources: Bloomberg, Consensus Economics; RBA. 


\section{Conclusion}

The international use of the RMB has continued to increase in the past few years, facilitated by policy initiatives applying within mainland China and to several offshore centres. For example, the designation of official RMB clearing banks has provided more direct mechanisms for settling offshore entities' RMB transactions with their Chinese counterparts. By facilitating RMB transactions, these clearing banks establish the necessary infrastructure for future progress in RMB internationalisation. The expansion of the RQFII program and the launch of the Stock Connect program have also increased the extent to which crossborder flows of RMB are liberalised, particularly flows into China.

There are a number of possible reasons why China is pursuing RMB internationalisation. These include ensuring that the status of the RMB reflects China's global economic weight, and also to reduce the currency risk faced by individual Chinese entities as the exchange rate regime is progressively liberalised. In addition, China may be pursuing RMB internationalisation to reduce the extent of currency mismatch on its aggregate balance sheet. To date, however, RMB internationalisation has instead tended to increase the degree of currency mismatch, partly because of pervasive expectations of future one-way RMB appreciation. Nevertheless, recent experience of greater two-way volatility in the RMB - and a growing market consensus that the RMB is unlikely to continue to appreciate monotonically against the US dollar-could change this over time. In any case, given that RMB internationalisation is closely related to the broader capital account liberalisation process, it is likely to continue to be pursued as a policy objective for some time. Until this broader capital account liberalisation process is completed - and potentially beyond thenthe offshore RMB market is likely to have an important role to play in $\mathrm{RMB}$ internationalisation.

\section{References}

Bank of China, Hong Kong (BOCHK) (2014), Offshore RMB Express, January, Honk Kong: BOCHK.

Calvo, G. and Reinhart, C. (2002), Fear of floating, The Quarterly Journal of Economics, 117(2): 379-408.

Cheung, Y.-W., Ma, G. and McCauley, R. (2011), Why does China attempt to internationalise the renminbi, in Golley, J. and Song, L. (eds), Rising China: Global challenges and opportunities, China Update Series, Canberra: ANU E Press. 
Frankel, J. (2012), Internationalization of the RMB and historical precedents, Journal of Economic Integration, 27(3): 329-65.

Hatzvi, E., Nixon, W. and Wright, M. (2014), The offshore renminbi market and Australia, RBA Bulletin, December, Sydney: RBA, Available from: www.rba.gov.au/publications/bulletin/2014/dec/bu-1214-7a.html.

People's Bank of China (PBC) (2014), Media Release No. 5, 15 March, Beijing: PBC.

Reserve Bank of Australia (RBA) (2014), Annual Report 2014, Sydney: RBA, Available from: www.rba.gov.au/publications/annual-reports/rba/2014/ pdf/2014-report.pdf.

Wildau, G. (2015), Renminbi not immune from emerging market outflows, Financial Times, 29 January.

$\mathrm{Yu}, \mathrm{Y}$. (2014), How far can renminbi internationalisation go?, ADBI Working Paper Series 461, Tokyo: Asian Development Bank Institute.

\section{Appendix}

To illustrate the relationship between RMB trade settlement and currency mismatch, we can consider three different states of the world:

1. China settles all of its trade in US dollars

2. China settles all of its trade in RMB

3. China settles more imports than exports in RMB (that is, the current situation).

For simplicity, in each scenario it is assumed the Chinese authorities maintain an independent monetary policy and a hypothetical fixed exchange rate of US\$1 = RMB5 (note that this highly stylised example implies that China must be closed to private capital flows, as per the standard 'trilemma' of international finance). China is also assumed to run a current account (trade) surplus of US\$5 billion (US\$10 billion of exports and US\$5 billion of imports).

In the first scenario - in which all current account transactions are settled in US dollars - the PBC must increase its foreign exchange reserves by US $\$ 5$ billion to maintain the RMB's fixed exchange rate against the US dollar (Table A11.1). This is equivalent to the PBC lending US dollars to the rest of the world to finance the rest of the world's current account deficit (relative to China). This increases China's international asset position by US $\$ 5$ billion. Regardless 
of whether the PBC chooses to sterilise its purchases of US dollars, its liabilities will increase by RMB25 billion (in the form of newly printed RMB or RMB loans from domestic entities).

Table A11.1 China's international assets and liabilities ${ }^{a}$

\begin{tabular}{|l|l|l|l|l|}
\hline & Exports & Imports & $\begin{array}{l}\text { Change in China's } \\
\text { net international } \\
\text { asset position }\end{array}$ & $\begin{array}{l}\text { Change in China's } \\
\text { foreign currency } \\
\text { reserves }\end{array}$ \\
\hline Scenario 1 & US\$10 billion & US\$5 billion & + US\$5 billion & + US\$5 billion \\
\hline Scenario 2 & RMB50 billion & RMB25 billion & + RMB25 billion & 0 \\
\hline Scenario 3 & US\$10 billion & $\begin{array}{l}\text { US\$4 billion }+ \\
\text { RMB5 billion }\end{array}$ & $\begin{array}{l}\text { + US\$6 billion - } \\
\text { RMB5 billion }\end{array}$ & + US\$6 billion \\
\hline
\end{tabular}

a Assuming the PBC maintains its fixed exchange rate of US\$1 = RMB5.

In the second scenario-in which all current account transactions are settled in RMB - the PBC must (on net) loan RMB25 billion to finance the rest of the world's RMB25 billion current account deficit. In turn, China's net international asset position increases by RMB25 billion. Unlike the first scenario, here, the PBC's assets and liabilities are both denominated in RMB, so there is no currency mismatch.

In the third scenario, we assume that all exports are denominated in US dollars (US $\$ 10$ billion), but the US\$5 billion worth of imports are partly denominated in US dollars (US\$4 billion) and partly in RMB (RMB5 billion). This means that there is a net US dollar inflow of US\$6 billion and a net RMB outflow of RMB5 billion (through trade). This RMB outflow is a liability on the PBC's balance sheet (for example, held as RMB deposits offshore), but the PBC must purchase the US\$6 billion inflow to maintain the fixed exchange rate, implying additional liabilities of RMB30 billion.

The currency composition of China's international assets and liabilities is different in scenario three (assets of US\$6 billion and a liability of RMB5 billion) to that in scenario one (assets of US\$5 billion). China's long foreign currency position, in fact, increases by more in scenario three, as the partial RMB denomination of imports means that there is a greater net inflow of foreign currency from trade. As a result there is a greater need for the $\mathrm{PBC}$ to acquire foreign currency reserves to offset this inflow. This demonstrates - in a highly stylised way-how the internationalisation of the RMB can result in a greater degree of currency mismatch on China's aggregate balance sheet than otherwise - if it results in a higher value of $R M B$ outflows than inflows. 
This text is taken from China's Domestic Transformation in a Global Context, edited by Ligang Song, Ross Garnaut, Cai Fang \& Lauren Johnston, published 2015 by ANU Press, The Australian National University, Canberra, Australia. 